\title{
Sustaining Community Living of the Very Old: Medical and Service Issues ${ }^{1}$
}

\section{A Manutenção da Vida Comunitária dos Idosos: Aspectos Médicos e Assistenciais}

\section{Collen L. Johnson ${ }^{2}$}

\begin{abstract}
FOHNSON, C. L. Sustaining Community Living of the Very Old: Medical and Service Issues. Cad. Saúde Públ., Rio de Faneiro, 10 (2): 149-163, Apr/fun, 1994.

The unprecedented prolongation of life in the United States has been accompanied by increased numbers of disabled people in their 80s and 90s, who have high needs for health care and social services. The paper reports longitudinal findings on 150 individuals, 85 years and older. Over three years, their functioning on activities of daily living significantly declined at the same time that they continued to described their health as good and to report contentment about their life. Families were active in sustaining community living of the oldest old, but those most at risk of institutionalization were the childless. Over time, $48 \%$ of the survivors stayed functionally fit, while $28 \%$ became increasingly disabled and dependent and $24 \%$ remained stable at a high level of disability. The means by which the oldest old coped with their disabilities include practical steps in simplifying their environment and narrowing their social world. They also used cognitive regulation by modifying their health beliefs and delimiting those areas over which they could exert a sense of control.
\end{abstract}

Key words: Aging; Longevity; Medical Assistance; Assistance to the Aged

\section{INTRODUCTION}

In recent years, there have been profound changes in the age distribution of our population. Not only are the numbers of people 65 years and older increasing rapidly, but also there have been dramatic increases in numbers of the very old (Rosenwaike, 1985; Taeuber \& Rosenwaike, 1992). In fact, a new age category has emerged among researchers, the oldest old or those 85 years and older. This unprecedented prolongation of life has far-reaching implications, not only for the

\footnotetext{
${ }^{1}$ This lecture stems from research, "The Social World of the Oldest Old" funded by the National Institute on Again (R37 AGO6559). Preparation for the paper was made possible by support from the 1992 Auniversity of California Health Net Wellness Lecture Award.

${ }^{2}$ Medical Anthropology Program. Center for Social and Behavioral Sciences. University of California, 1350 Seventh Avenue, CSBS-317, San Francisco, California 94143, USA.
}

aged and their families but also for the providers of health care and social services. Since declines in mortality have not been accompanied by declines in morbidity, members of this age group are especially vulnerable (Verbrugge, 1984). As a consequence, new challenges have emerged for the providers of health care and social services.

This paper will use finding from a longitudinal study of individuals 85 years and alder who are sufficiently independent to live in the community. Our purpose has been to map the competencies needed to adapt to the predictable problems of advanced old age. Adaptation is defined here as simply the ability to sustain community living through the successful manipulation of the physical and social environment and, psychologically, the maintenance of motivations and morale.

In the following, I will first report on the needs created by the vulnerabilities the very old face. Second, the process by which these 
needs are addressed will be discussed at four levels: (1) the actions of their families and informal social networks; (2) the responses of the social service institutions; (3) the role of the health care system; and most importantly, (4) the individual and his or her coping skills. Third, by singling out survivors who are still living in the community three years after the study began and comparing them to those who died, who became too incapacitated to continue in the study, or who were institutionalized, we will able to identify the various trajectories occurring over this time.

Because of the many nonmedical problems that complicate the treatment of chronic diseases, health is defined here broadly to include the environmental, psychological, and social consequences of disability. Here the individual is viewed as an active agent in managing the complex tasks not only in dealing with the pain and disability of chronic conditions of late life, but also in mobilizing support and sustaining a sense of well-being. I will illustrate how relatively small events can upset the fragile equilibrium of the oldest old, but commonly small but sustained interventions can improve their functioning, the quality of their lives, and ultimately their ability to sustain community living.

\section{BACKGROUND}

A lively debate rages between two camps as to whether the prolongation of life will eventually result in a very old population which, through good health habits and the efforts of the health care system, is able to sustain adequate physical functioning until near death (Fries, 1980). Given the fact, however, that large numbers of the oldest old are functionally impaired, such optimism is not yet justified (Guralnik, 1991). Because vulnerabilities tend to cluster among the disabled, the oldest risk being socially and economically vulnerable as well (Kovar, 1986; Longino \& Soldo, 1987). Not surprisingly then, $20-25 \%$ of the oldest old live in institutions, and a similar proportion are in need of extensive long-term care services. Thus, we are encountering an unfamiliar set of problems created by the prolongation of life, which requires new and long-range solutions. The major problem, understandably, is the need to reduce the period of morbidity among the very old in their final years of life (Riley \& Bond, 1983).

When the study began in 198, very little was known about members of this age group beyond scattered demographic and epidemiological reports. In fact, when the National Institute on Aging issue a request for proposals in 1984, it pointed out that even though the federal government spent $\$ 40-45$ billion for services for those 80 years and older, less was known about that age group than any other one in the country (Longino, 1988). While more information is slowly becoming available, there remains a persistent practice in the census-taking and in survey research of making few age distinctions after age 65 . Even by 1980 , there were fewer cross tabulations by age after age 65 than in the previous census. Not only do we need more information on the oldest old, but some research also suggest that we must incorporate new research methodologies in order to tap the subtle process of adapting to long-term survivorship and to understand the subjective aspects as well as objective factors of the prolonged aging process (Dean, 1992). Hopefully, anthropological approaches can begin to identify these.

On the optimistic side, despite the large majority who are functionally impaired, $75 \%$ $80 \%$ of the oldest old are still living more or less independently in the community (Kovar, 1986). But practically speaking, because of this impairment the efforts to compress morbidity during the final years of life are usually overshadowed by the demands placed upon providers of health care and social services to deal with the many ongoing vulnerabilities of the oldest old. Not surprisingly the rates of doctors visits and hospitalizations are high for this age group) Manton \& Suzman, 1993). As they inevitably undergo age-related physical changes, the oldest old are also subject to the stressors stemming from their potential loss of control 
of their physical and social environment, losses that ultimately can affect their health and well-being (Rodin \& Temko, 1992).

In addition to losses in functioning, the very old have generally outlived their contemporaries and thus have experienced many social losses as well (Johnson \& Troll, 1992). With the disparate gender-based life expectancy, there are only 42 males per 100 females in the 80 to 84 age group a (Taeuber $\&$ Rosenwaike, 1992). Consequently, few women - only $8 \%$ - are married, and as many as one-third of the men and women are childless. A major risk, then, in advanced old age is the possibility not only of outliving their contemporaries, but also of outliving family life. Nevertheless, such a picture is not as grim as the evidence suggests, for a majority of the very old tend to report that their health is good or excellent (Kovar, 1986; Rodin \& Temko, 1992), a perceived health status that is much more optimistic than their level of disability would indicate (Verbrugge, 1984). Consequently, and despite social and physical losses, the widespread contentment found among the oldest old seems particularly remarkable, a situation which I will explore in the following.

\section{THE STUDY}

To select 150 individuals of age 85 years and older, public voting records in San Francisco were used along with a snowballing technique whereby respondents secured from the voting records referred us to their age peers. The voting records include date of birth and usually current addresses. Only whites were interviewed initially, but currently interviews with a sample of AfricanAmericans, 85 years and older is nearing completion. Letters were sent to individuals, 85 years and older, followed by a telephone call to schedule an interview. Of those contacted who were judged competent enough to be interviewed, $24 \%$ refused. Time 2 and Time 3 interviews occurred at 14-16 month intervals.

Interviews lasting two to there hours were held in the respondents' homes and conducted either in one or two sittings. A focused interview technique was used, one which combined both open-ended questioning and standard instruments. The Bradburn Affect Balance Scale and a self-report question measured mood. There were three measures of physical status: (1) functioning was evaluated by two scales, the Activities of Daily Living which measures items of personal care such as independence in hygiene, feeding, and transfer (Katz et al., 1963), and the Instrumental Activities of Daily Living(Duke University, 1976), which taps the ordinary activities of daily life, such as management of money, medications, movement outside the home and so on; (2) subjective health as determined from the respondents' self report on a 4-point scale; and (3) the number of reported diseases, determined from data collected at Time 2). Other than these scales and specific questions on their family relationships, respondents ranged freely in their discussions. The qualitative portion of each interview was coded by two members of the research staff with an intercoder reliability of $81 \%$. To explore the adaptive challenges common in advanced old age, we asked respondents about their daily routines - the pacing of their activities, how they handle their daily mundane tasks, whom they see, and what events make good days and bad days. The responses provided rich information about how they were coping with functional impairment.

The sample is well distributed throughout the socio-economic levels. In education, roughly one-third have at least some college, another one-third a high school diploma, and one-third less than a high school degree. These figures are comparable to those reported for whites elsewhere who are 85 years and older. More than half half had worked in blue collar or lower-level whitecollar positions before their retirement, while most of the remainder were in the upper middle class. In religious affiliation, $42 \%$ are Protestant, 35\% Catholic, and 23\% Jewish. Economically, 58\% report their resources as very good. In fact, most of them describe it as better than they had expected. 


\section{Strengths and Vulnerabilities of the Oldest Old}

When compared to national surveys of people 65 years and older, the families and social networks of the respondents studies here apparently have experienced some attrition over time (Cornoni-Huntley et al., 1986; Shanas, 1979a, 1979b). Their mean age was 89 years at Time 1 and 92 at our last contact. A lar-ge majority, 73\%, are women; only $20 \%$ are married; and as many as $58 \%$ live alone (Table 1). One-third of the respondents are childless; the same proportion have at least one deceased child; and $45 \%$ have no child in the area. Thus, this sample is dominated by unmarried women who live alone, many of whom do not have the support of a child. In fact, $24 \%$ no longer maintain any face-to-face family interactions. Most of these physical and social characteristics, however, are similar to those oldest old reported elsewhere who still live in the community (Bowling \& Browne, 1991; Kovar, 1986; Cormoni-Huntley et al., 1986).

TABLE 1. Social Characteristics, Time $1(n=150)$

\begin{tabular}{lc}
\hline \hline Mean age: & 8.95 \\
Gender: & \\
Male & $26 \%$ \\
Fernale & $74 \%$ \\
Marital status: & \\
$\quad$ Not married & $80 \%$ \\
Married & $20 \%$ \\
Household: & \\
Alone & $58 \%$ \\
$\quad$ With others & $42 \%$ \\
Parent status: & \\
$\quad$ At last one surviving child & \\
At last one child in proximity & $69 \%$ \\
At least one deceased child & $55 \%$ \\
Social class: & $32 \%$ \\
$\quad$ Mean education & \\
Former occupation: & 12 years \\
$\quad$ Blue collar & \\
White collar & $28 \%$ \\
Professional/managerial & $25 \%$ \\
Religion: & $47 \%$ \\
Protestant & \\
Catholic & $42 \%$ \\
Jewish & $35 \%$ \\
\hline \hline
\end{tabular}

Turning now physical status and mood, we note that a large majority of the oldest old, $73 \%$, report that their health is either good or excellent (Table 2). Even more, 79\%, judge that their health is better than their contemporaries, and more than two-thirds never worry about their health. Only $31 \%$ however, are able to perform all of the activities of daily living without help. As to their mood, most report they are very contented or mostly contented. Surprisingly, such positive views of their status occur in the context of a high level of functional impairment. 
TABLE 2. Physical and Mental Status, Time 1

Perceived health:

Compared to Contemporaries:

$\begin{array}{ll}\text { Good/excellent } & 73 \% \\ \text { Fair/poor } & 27 \%\end{array}$

Functioning (ADL/IADL):

$\begin{array}{ll}\text { No disability } & 31 \% \\ \text { One or more activity } & 69 \% \\ \text { ood: } & \\ \text { Conteted } & 62 \% \\ \text { Mostly contented } & 62 \% \\ \text { Discontented } & 12 \%\end{array}$

Disease Conditions (\%)

(Self report)

Most common:

Arthritis/rheumatism

Bone disease/fractures

Hypertension

Cardiovascular disease
$62 \%$

$12 \%$
$79 \%$

$21 \%$

Health worries:

None $\quad 67 \%$

Some $\quad 33 \%$
Table 2 also lists the most common and least common diseases these oldest old report. Understandably in view of their disabilities, $68 \%$ report having arthritis or rheumatism, and $57 \%$ report bone disease, such as osteoporosis, fractures, or other problems with the lower extremities. Hypertension occurs among $48 \%$ of the sample, a figure that may be higher a clinical diagnosis because self reports tend to refer to intermittent incidence rather than persistent hypertension. In any case, hypertension. Thirty-eight percent report heart problems. Other than cardiovascular problems, the oldest old have escaped those diseases, that are the leading causes of death. Only $2 \%$ have diabetes, $7 \%$ have asthma, $13 \%$ have had a stroke, and $14 \%$ have had an incident of cancer.

In summary, the frail elderly who survive usually have escaped the infectious diseases of childhood and those diseases that are the major causes of death in late adulthood. In advanced old age, then, most suffer from disabling chronic conditions that have no
Least common:

Diabetes 2

Asthma 7

Stroke 13

Cancer 14 direct relationship with the leading causes of death. Given the positive views of their health despite their disabilities, we have been impressed by the strengths of the oldest old. Perhaps unique to this age group, the presence of disabling physical problems among them does not necessarily lead to the usual psychological effects of poor health.

\section{CHANGES OVER TIME}

\section{Attrition}

Over a three-year period, $19 \%$ of the original 150 respondents died, $11 \%$ became too impaired mentally or physically to participate in a two-hour interview, and 9\% either refused to participate or could not be located. Twenty-four individuals, $16 \%$ of the sample, relocated during the study, most because their disabilities made independent living too difficult to sustain. Of these, 12 entered a nursing home, and 9 others entered a board-and-care home or congregate senior housing. 
TABLE 3. Comparisons of Survivors (\%) at Time and Dropouts (\%) Over Three Years

\begin{tabular}{lcc}
\hline \hline & $\begin{array}{c}\text { Survivors } \\
(\mathrm{n}=90)\end{array}$ & $\begin{array}{c}\text { Dropouts } \\
(\mathrm{n}=60)\end{array}$ \\
\hline Perceived health: & 75 & 70 \\
$\quad$ Excellent/good & 25 & 30 \\
Fair/poor & & \\
Functioning: & 36 & 21 \\
$\quad$ No impairment & 36 & 30 \\
Impaired, 3 or less activities & 28 & $\star \star \star 49$ \\
Impaired, or more activities & & 61 \\
Mood: & 59 & 39 \\
$\quad$ Contented & & \\
Intermittent discontentment or & 41 & 42 \\
$\quad$ discontented & & 58 \\
Family integration: & 67 & \\
High & 33 & 28 \\
Medium or low & & \\
Friendships integration: & 44 & 34 \\
Active & 56 & 66 \\
Somewhat active or Inactive & & \\
Associations: & 49 & \\
Active & 51 & \\
Somewhat active or Inactive & & \\
& & \\
\hline \hline
\end{tabular}

${ }^{\star} \mathrm{p}<.05 ; \star \star \mathrm{p}<.01 ;{ }^{\star \star \star} \mathrm{p}<.001$

In comparing those lost to the research to those who continued, we find few differences, except for the fact that the dropouts initially were more impaired on the Instrumental Activities of Daily Living than the survivors. This finding is consistent with that of Gurilik whofound such declines in the last year of life. Also, the nonsurvivors had already begun to withdraw from their friendship network and community activities because of these declines in functioning (Table 3).

\section{THE SURVIVORS OVER TIME}

Taking now the 90 respondents who remained in the study over the e-year period, comparisons of their status at three contacts over three years indicate few changes in perceived health and mood, but there is a persistent decline in the Instrumental Activities of Daily Living. Similar findings reported by others point to the problem at hand (Guralnik, 1991). At the very end of their lives, the oldest old find it increasingly difficult to manage their daily activities handing their medications, their finances, their shopping, and most prominently, their mobility outside the home. For all those still living outside institutions, most can still take care of their personal hygiene, feed themselves, and move from their bed to a chair without help, all activities that would require full-time help if individuals could not perform them independently. To address the problems in managing a household 
independently, as indicated by the instrumental Activities of Daily Living, intermittent help is necessary rather than the more expensive round-the-clock assistance.

FIGURE 1. Changes in Health, Functioning, and Mood Over Three Years $(\mathrm{n}=90)$

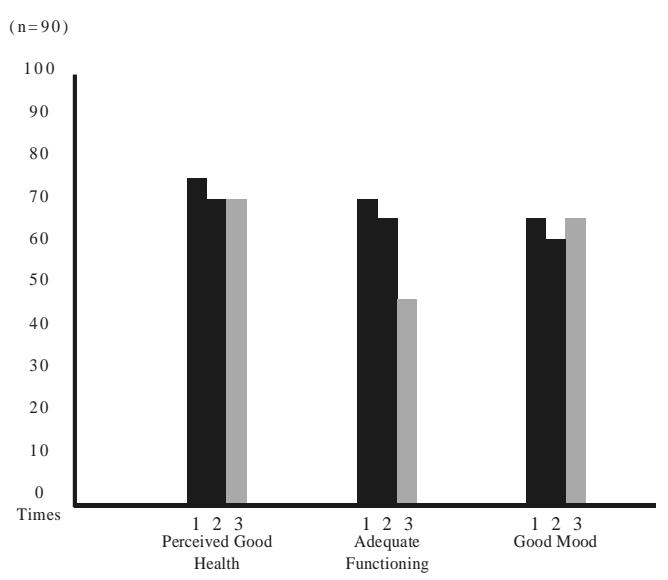

\section{RESPONSES TO THE NEEDS OF THE OLDEST OLD}

\section{Family Responses}

Given the high level of disability, the families of these respondents can play an important in sustaining community living. Almost one-fourth of the sample, however, maintain no regular family contacts, other than annual letters or phone calls with distant relatives. Those without active family relations are more likely to be childless. Where children are present, they function as the linch pins in orchestrating a support network for their very old parents, even if they do not provide hands-on care.

Table 4 divides the sample according to parent status and compares the childless (31\% of the sample) to those with a surviving child. The assistance from a family member in helping with daily activities (ADL/IADL) is not available to most of the childless, indicating that other family members do not function as substitutes. The childless are also

TABLE 4. Social Network Responses to Needs

\begin{tabular}{|c|c|c|}
\hline Family & Childless (\%) & Parents (\%) \\
\hline $\begin{array}{l}\text { ADL/IADL help: } \\
\text { Another family member } \\
\text { Friends }\end{array}$ & $\begin{array}{l}21 \\
21\end{array}$ & $\begin{array}{r}\star \star 60 \\
14\end{array}$ \\
\hline $\begin{array}{l}\text { Contacts, weekly or more: } \\
\text { Child } \\
\text { Grandchild } \\
\text { Relative } \\
\text { Friend }\end{array}$ & $\begin{array}{c}- \\
- \\
17 \\
83\end{array}$ & $\begin{array}{l}64 \\
27 \\
10 \\
67\end{array}$ \\
\hline $\begin{array}{l}\text { Caregiving: } \\
\text { Family member } \\
\text { Needed, not receiving } \\
\text { Not needed }\end{array}$ & $\begin{array}{l}17 \\
33 \\
44\end{array}$ & $\begin{array}{l}45 \\
11 \\
41\end{array}$ \\
\hline $\begin{array}{l}\text { Potential caregiver: } \\
\text { Family member } \\
\text { No one available }\end{array}$ & $\begin{array}{l}26 \\
74\end{array}$ & $\begin{array}{r}91 \\
\star \star \star 9\end{array}$ \\
\hline \multicolumn{3}{|l|}{ Formal Supports } \\
\hline Use of Formal Supports & \multicolumn{2}{|l|}{$\begin{array}{l}\text { None } \\
\text { One } \\
\text { Two or more }\end{array}$} \\
\hline \multicolumn{3}{|l|}{ Health care Utilization } \\
\hline $\begin{array}{l}\text { Mean physician visits: } \\
\text { Annual hospitalizations: }\end{array}$ & $\begin{array}{l}3.55 \text { annually } \\
\text { Time 1/Time } 2 \\
\text { Time 2/Time } 3\end{array}$ & $\begin{array}{l}38 \% \\
37 \%\end{array}$ \\
\hline
\end{tabular}


no more likely to be in contact with a relative, although they do have more contact with friends. As to the availability of a caregiver, only $17 \%$ of the childless have a family caregiver, and one-third of those in need are not receiving that kind of help. Of those who are not currently in need, most parents can turn to a family member, while as many as $71 \%$ of the childless have no one to perform that role if needed, thus making them more vulnerable.

\section{Formal Supports}

We find that most who need help tend to use at least housekeeping assistance, irrespective of the actions of their families. Yet it is important to note that for those who are impaired in their activities of daily living, there are no significant differences in the use of formal supports. Such a pattern may be due to the aging of the families of the oldest old. Their children, whose mean age is approximately 60 , may themselves be experiencing some of the problems of old age, such as widowhood, relocation, and the onset of chronic diseases. In such cases, they are not able to assume a care giving role on a regular basis

\section{The Health care System}

The health care system is also active in the care of the very old; $62 \%$ visit their doctor on a regular basis, at least every three months or more. Hospitalizations are also frequent: $38 \%$ were hospitalized in the preceding 15 months preceding our second contact, and $37 \%$ were hospitalized during the 15 months between Time 2 and Time 3.

\section{INDIVIDUAL RESPONSES}

\section{Handling Daily Tasks}

The very old tend to maintain themselves in the community through the practical management of their physical and social environment. Individuals manipulate their physical environment by four maneuvers that make it congruent with their level of functioning. First, with functional impairment, respondents usually narrow the boundaries around their physical world to make their environment more manageable. Living surrounding are sometimes stripped of all extraneous objects to make housekeeping easier. Some individuals place soft furniture in strategic places where they might fall.

Second, their functioning is usually enhanced by the use of appliances: canes, walkers, and special railings to increase their mobility, and hearing aids and magnifying glasses to improve their sensory acuity. Coping with limitations on their mobility outside the home is more challenging, but it stimulates some innovative solutions. When walking outdoors, some respondents use a grocery cart filled with bags of cement to stabilize themselves. Other individuals who are still able to go out alone exercise caution by planning to use traveled bus routes or, if they still drive, by plotting out their itinerary to avoid difficult left turns.

Third, to further enhance their control over the environment, establishing a routine daily plan serves to create a stable and predictable environment. Days are methodically scheduled to pace their activities so there is neither too much nor too little to do. This highly structured routinization of daily activities also results in the ritualization of the mundane aspects of daily life, a process that gives their daily lives more significance (Turner, 1969).

\section{Cognitive Self-Regulation}

I propose here that the very old individuals are active agents in devising their own means of adapting to long-term survivorship. Such coping techniques, however, are not always based on an accurate perception of reality. Instead, many re-interpret the real world to make it more attuned to the physical and social losses they have experienced. A body of research by Leventhal and his colleagues (Lewenthal et al., 1992) is relevant to the oldest old. He proposes a complex model of self regulation in which the process of vigilance is used to regulate one's health. 
Older individuals, he finds, show fewer signs of emotional distress in dealing with their health problems. In fact, there are consistent declines in emotional reactions and less worry and anxiety about their health. Consequently, there are age-related differences in coping strategies, whereby the old are more likely than younger individuals to be motivated to reduce the level and causes of emotional distress that potentially stem from poor health.

While practical actions assist them in adapting to their health problems, modifying their health beliefs can provide meaningful explanations regarding their situation. First, respondents commonly use their age peers as a reference point so as to be able to define their own health as superior. No matter how frail and debilitated these respondents are, they point to many others who are in worse shape. For example, some individuals assume they are better off by the mere fact that they can get out bed each day. Others conclude, "Thank goodness, I have all my marbles," or "I can still walk with a walker. I see so many younger people who are in wheelchairs". One woman who was unable to stand up unassisted described her health as better than others because she didn't have "breathing or heart troubles". Some survivors insist they have no reference group: "I don't know anyone my age. They are all dead".

Second, these very old individuals also tend to disassociate their body from an illness episode or a disease state. On the one hand, they may simply attribute their symptoms to old age. "I can't breathe lying down, but AI don't have a disease. Now I just have old age". On the other hand, they can use denial. For example, one 89-year-old woman had been hospitalized twice in the previous year. A bout with pneumonia was passed off: "It was nothing. Look at me, you can tell nothing happened". Some months later she had an allergic reaction to seafood requiring a hospitalization. "It is not my body that had anything to do with it. It was the clam chowder". She also denies disease conditions: "I' $\mathrm{m}$ full of aches and pains but it is not arthritis".

A third type of reaction to their symptoms is to constrict those areas over which they can exert personal control. The old tend to be less frightened by illness and are usually skilled in distancing themselves from concerns about their physical problems. Often a sense of inevitability, fate or luck dominate their discussions. "I'm like an old car - the parts are wearing down". Such a fate is often viewed as natural, "There is a time to live and a time to die. I'm ready to go any time. "Their health may be attributed to genetic endowment", "I had the right parents", their religion, "I am healthy because I follow the rules of the Mormon Church", or sheer luck, "God forgot me". These positive views are expressed even among those with high impairment. "What can I say, I've had bypass surgery, I now have shingles, I'm isolated and lonely, I'm losing my strength and my confidence in myself. But glory be to God, I'm feeling well”.

\section{TRAJECTORIES OVER TIME}

Events impinging upon the oldest old through time hinge upon their health status and their level of disability. First, over three years, $48 \%$ of the survivors stayed functionally active, either with no impairment (19\%) or impairment on only three or fewer activities (29\%). Second, the functional status of another $28 \%$ deteriorated over that time to the point that their independence was threatened. Third, the physical status of the other $24 \%$ of the sample remained stable over time but at a very impaired level of functioning. Table 5 reports the quite disparate needs and resources found among these very old respondents over time.

Of the 90 survivors over the three years of the study, we find some interesting continuities and discontinuities. First, in their perceptions of their health status, it is remarkable that those who are very disabled and those who experience a precipitous decline in functioning usually continue to view themselves as healthy and express few worries about their health. Interestingly the level of contentment declines with increased disability but not significantly so, all of which reflects the propensity among the very old to control the emotional consequences of 
physical problems. Second, the social adaptation of the oldest old differs by the physical trajectories of these very old individuals. Physical declines are associated with decreased involvement with friends and community activities, although family involvement does not vary significantly.

Table 5 also presents findings relevant to the providers of help to the oldest old. With increased impairment, they use more formal supports but are no more likely to visit a doctor more frequently. Quite unanticipated, however, are the findings regarding hospitalizations. The chronically impaired are significantly less likely to be hospitalized, only $22 \%$ in comparison to $64 \%$ of those whose physical status declines and $40 \%$ whose functioning remains adequate over time. Thus, the most expensive form of intervention, hospitalization, does not appear to be directly related to level of disability.

TABLE 5. Trajectories over Time

\begin{tabular}{|c|c|c|c|}
\hline & $\begin{array}{l}\text { Stable/Adequate } \\
\text { Functioning } \\
\text { (43) } 48 \%\end{array}$ & $\begin{array}{l}\text { Declines } \\
(25) 28 \%\end{array}$ & $\begin{array}{l}\text { Stable/Poor } \\
\text { Functioning } \\
\text { (22) } 24 \%\end{array}$ \\
\hline $\begin{array}{l}\text { Perceived Health: } \\
\text { Good/excellent } \\
\text { Fair/poor }\end{array}$ & $\begin{array}{l}72 \% \\
28 \%\end{array}$ & $\begin{array}{l}67 \% \\
33 \%\end{array}$ & $\begin{array}{l}68 \% \\
32 \%\end{array}$ \\
\hline $\begin{array}{l}\text { Health worries: } \\
\text { None } \\
\text { Some }\end{array}$ & $\begin{array}{l}58 \% \\
42 \%\end{array}$ & $\begin{array}{l}76 \% \\
24 \%\end{array}$ & $\begin{array}{l}71 \% \\
29 \%\end{array}$ \\
\hline $\begin{array}{l}\text { Mood: } \\
\text { Contented } \\
\text { Discontented }\end{array}$ & $\begin{array}{l}68 \% \\
32 \%\end{array}$ & $\begin{array}{l}52 \% \\
48 \%\end{array}$ & $\begin{array}{l}43 \% \\
57 \%\end{array}$ \\
\hline $\begin{array}{l}\text { Social Integration with } \\
\text { Family } \\
\text { Friends } \\
\text { Associations } \\
\text { Adequate finances }\end{array}$ & $\begin{array}{l}53 \% \\
67 \% \\
58 \%\end{array}$ & $\begin{array}{l}50 \% \\
16 \% \\
12 \%\end{array}$ & $\begin{array}{r}59 \% \\
\star \star \star 24 \% \\
\star \star \star 18 \%\end{array}$ \\
\hline $\begin{array}{l}\text { Formal support: } \\
\text { None or one service } \\
\text { Two or more } \\
\text { Physician Visits } \\
\text { Annual (means) }\end{array}$ & $\begin{array}{l}39 \% \\
61 \%\end{array}$ & $\begin{array}{l}13 \% \\
87 \%\end{array}$ & $\begin{array}{r}\star \star \star 16 \% \\
84 \%\end{array}$ \\
\hline $\begin{array}{l}\text { Hospitalizations: } \\
\text { (previous year) } \\
\text { None } \\
\text { One or more }\end{array}$ & $\begin{array}{l}60 \\
40\end{array}$ & $\begin{array}{l}36 \\
64\end{array}$ & $\begin{array}{r}\star 78 \\
22\end{array}$ \\
\hline
\end{tabular}

$\mathrm{p}<.05 ;{ }^{\star \star} \mathrm{p}<.01 ;{ }^{\star \star \star} \mathrm{p}<.001$ 


\section{Stable Functioning}

It is of interest, consequently, to turn to descriptive case studies to track how disability and acute illnesses are experienced over time. Despite being more functionally fit than others in the sample, these respondents surprisingly did not differ from the more impaired in their incidence of life-threatening diseases. In fact, $40 \%$ described hospitalizations, surgeries, and severe illnesses from which they recovered or at best moderated the symptoms to the extent that their functioning was restored.

Mrs. E., an 87 year old widow, provides an example of the functionally fit who nevertheless must deal with serious health problems. Over the three years in this study, she has had no impairment on her activities of daily living, and she leads an active social life, going to concerts and socializing with her many friends. Although functionally fit, she described her health as average. "Right now I'm a little under the weather". She also complained of pain in her hips when walking. Between our contacts she was hospitalized for "blocked arteries" in her legs. Much to her regret, the procedure to clear them was unsuccessful. Thus, she has had further difficulty in mobility, but she did not curb her social activities. Rather than walking to stores and friends' homes, she drove. Despite worries about her health, she reported that her health was good.

By Time 3, she had occasional blackouts and fainted once at a dinner party. She also complained. "I have atypical angina, which makes me feel like a stuffed doll". Nevertheless, she continued her positive thinking about her health: "I realize I have to get it into my mind that I'm 90 and that I'm going to die. It's big adjustment to know I'm never again going to walk easily, that I'm going downhill and have less energy".

Despite these health problems, however, Mrs. E. had mo limitations on her activities either inside or outside the home.

\section{The Chronically Disabled}

In contrast to the functionally active, who remain so even after episodes of acute illnesses, one-quarter of the survivors had a poor level of functioning throughout the study. Their functional problems could usually be traced to their chronic conditions rather than life-threatening diseases. As some reported, "The only thing wrong with me is old age". They were more likely to complain of arthritis, painful joints, and hip problems as the following indicates. Generalized complaints such as "I'm just tired", "It's just a cold hanging on", or "It's the flu I can't shake" were typical. Mrs. G., a 92 year-old widow, illustrates problems with chronic diseases. She lives alone but has one daughter in the area. Six weeks previous to the first interview, she had fallen and broken her shoulder. Upon her discharge from the hospital, she entered a demonstration project and received round-the-clock care and a case manager to oversee her many helpers. While needing help in most of her activities, she described her health as "pretty good", because she had had a flu shot. "I've been a little sick lately, but that's nothing new. I only take a little Tylenol".

Before our second contact, she delayed the interview because, she said, "I'm tired and have to stay in bed". She finally agreed to our visit, "but I might fall asleep on you". Her appearance was disheveled and she was dressed in a soiled bathrobe and pajamas. Her memory was so poor that she could not recall her injury and the formal supports she had received in the previous year. She remained impaired on five activities of daily living, yet she received very little help. Apparently she no longer qualified for service benefits and no even say a physician. Her daughter took care of her finances, a neighbor cooked her dinner, and she had groceries delivered. As to her health, she reports, "I'm on my way out of some illness now. I think it is just old age. I'm just tired all the time and have a lot of aches and pains".

By our next contact, her situation had worsened. She was impaired on eight activities, and despite noticeable cognitive problems, she was still living independently. She had outside help two hours a day. She described her health as poor. "You see, I move very slowly. I just can't do anything. I 
think it is because I'm getting older". Shortly after the third interview, she was

institutionalized.

Some of these seriously disable respondents spoke of wanting to die. Mrs. F. was an 86-year-old, childless, unmarried woman her nephew. Since a stroke three years previously, she was confined to her bed or wheelchair. She described her health as good but complained of pain and feelings of helplessness. By the next interview, her health had deteriorated further. She reported, "I'm hopeless case. I can't do anything any more. Being old is pure hell - the hardest thing for me now is having to go on living". Six months later, her nephew called to tell us of her death because "her heart just stopped".

\section{The Cascade Effect}

"The cascade effect" is sometimes used by geriatricians to refer to a situation in which disease conditions and iatrogenic effects of their treatment combine to initiate a downward spiral in a patient's status. A parallel process was observed among some of our respondents where interactions between physical, social, and psychological problems eventually led to institutionalization or death. Declining functioning, pain, and loss of energy commonly led to a lowered capacity to socialize, thus resulting in a shrinking social world. As problems become compounded, some individuals became depressed and anxious. Others experienced declines in their cognitive capacity, a situation that further diminished their social competence.

Two people also died from complications after falls. For example, at our second contact. Mrs. G. at age 93 was anxious because her husband was critically ill and in the hospital. Without him around, she was having increasing difficulty keeping track of her medications. Three months after our last contact, she fell down the stairs where she lay for 12 hours unattended. She was in a coma for 10 days before her death.

In some cases, dramatic declines were noted after a seemingly easily resolvable event. For example, at our first and second contact, Mrs. A. was an attractive, well-groomed widow who initially led an active life surrounded by family and friends. She reported her health as excellent and early maintained her own home, doing all the gardening and domestic chores. Most days she took public transportation downtown to a restaurant that she referred to as a "widow's hangout", where she met her friends. Her family was attentive, calling daily and visiting weekly.

Her contentment with life changed dramatically after she fell and shattered her knee. After an infection and skin graft, she was transferred from a hospital to a convalescent home, where she received physical therapy. After a month, she was rehospitalized, this in a psychiatric ward. In our contacts with her there, she was confused and disoriented. A few weeks later she was again transferred, this time to a board and care home, where she was lucid but spent all her time in bed. She refused to walk and became incontinent. To compound her problems, a family conflict of unknown origin arose with her decline in functioning. As Mrs. A. herself concluded at our last contact, "Why should I have this kind of exit. I've tried to lead a good life. I've worked hard all my life so my children could be comfortable". She also concluded that she will never return to her home, so her children were dividing up her furnishings.

There are some reversals to such negative outcomes, but ones that can only be identified by extensive longitudinal study. For example, Mr. Jones, 88 years of age at our first contact, was still enjoying his life, his family and his friends, and except for a pacemaker, he had few health complaints. By our second contact, however, he reported a hospitalization and extended radiation treatments for a tumor in his back.

Nevertheless, he continued up to be socially involved. By the third contact, three years later, his wife told us he was too ill with cancer to see us. His wife seemed very anxious, "We are not doing well. I'm 87 and he's 91. We have no help and I don't know how long I can manage". At our fourth contact, she did permit us to stop by "for a minute". To our great surprise, $\mathrm{Mr}$. Jones met us at the door, dressed and neatly groomed. 
He felt sufficiently well that he concluded the diagnosis of cancer must have been in error. They did have some minor service needs which were addressed with a minor intervention. He had given up his car during the course of his illness. Mrs. Jones had had a slight stroke and had difficulty shopping and cooking. Nonetheless, their problems were at least temporarily solved by a minor intervention, that is, the provision of Meals on Wheels.

\section{AT THE END OF A LONG LIFE}

In their eighties and nineties, the imminence of death is a given, a subject that is constantly in the thoughts of the oldest old. Successful adapters commonly come to terms with their own mortally and consider some advantages to long-term survivorship. One interpretation about long-term survivorship is the conclusion that one has already experimental all possible negative events. Deciding that all bad experiences have already happened to them, "There is nothing left to worry about". Having outlived the normal worries about their health, respondents commonly shed fears about their mortality.

With this stance, fatal illness can become viewed with equanimity. Disease and impairment are commonly deemed as irrelevant. For example, one woman who was recently diagnosed with cancer was unperturbed, as she said, "That's no worry - at my age, I have to die of something". Another respondent also emphasized his unique status: "I have had a stroke, an irregular heart beat and walking pneumonia. I take five pills a day. But what do you expect from someone my age. Most of my friends died in their 60s or 70s". One woman also spoke with detachment, "To hear me moaning, you'd think I am dying, but it's appropriate to describe my health as good. Lost is wrong but nothing is incapacitating. I have a form of cancer which will be fatal, but who knows when. I was given four years and now it's seven years later". Such comments suggest that even death can become a benign force.
In simplifying her world in her final year of life, one centenarian expressed this viewpoint "When you are 100 years old, you can't help but think of death. But I enjoy my life. I put time out of mind. I try to look forward and push away death. At this age, one has new eyes again. I put a frame around my life and see only what I want to see. AI forget about what I can't do anymore and develop new intuitions and feelings. Of course, those are my daytime ideas. My night dreams are different. My unconscious takes over and I have no control".

\section{IMPLICATIONS FOR PROVIDERS OF HEALTH CARE AND SOCIAL SERVICES}

In conclusion, this in-depth longitudinal study permits us to make several conclusions. First, because of their impressive physical and social losses, the oldest old are especially vulnerable even to seemingly unimportant events. A fall may lead not only to a hospitalization, but also to limitations on mobility outside the home and subsequently a drastic change in lifestyle. Problems with overmedication may lead to a temporary dementia and sometimes, unfortunately, a diagnosis of irreversibility. Eviction from a long-term residence may lead to social isolation and perhaps an unnecessary institutionalization.

Most oldest old who still live in the community have difficulty in managing their households and performing daily maintenance tasks; they do not usually require comprehensive long-term care services and round-the-clock care. Those who are unable to handle their personal care are more likely to be institutionalized. In contrast, assistance on daily tasks usually entail small interventions which easily address the problems: Meals on Wheels, special transportation, friendly visitors, and so on. Very old disabled individuals also require a regular source of assistance in household tasks and transportation.

The problems for may is the lack of familiarity with the social service system. Most middle-class elderly tend to view the social 
worker as a helper of the poor and are thus inexperienced in navigating through the social service bureaucracy. They also tend to lack the knowledge of available services and those for which they quality. Large numbers in the middle class are particularly vulnerable; they may still own their homes, which they maintain with only modest resources.

Consequently, they are not eligible for these services, yet they do not have sufficient income to secure help independently. For many then, knowing where to turn and taking the first step in finding formal assistance is a difficult and unfamiliar endeavor and one that often fails to secure needed help.

Parallel problems in finding adequate health care are rarely encountered. Most of the oldest old are regular users of health care and have Medicare and often other insurance to cover the costs. Problems arise, however, because their primary-care physician is generally in private practice and usually similarly unfamiliar with the many community services available to older people.

Essentially, the hospital, through their discharge planners, is the most effective institution that functions as a mediary and link between the very old and the social services institutions in the community. Given the high rate of acute inpatient care among these respondents, one wonders how many incidents could have been addressed in the community, if there were coordinated care for the oldest old in all walks of life, not just recipients of Medicaid and other public benefits.

The challenge today to the health care system are twofold. First, there is a need to find some means to reduce the symptoms of the chronic diseases afflicting the oldest old. Independent living would be facilitated and the quality of live improved if the symptoms of the dementias, arthritis and circulatory problems could be moderated. Second, in dealing with the ever growing older population, it is time too think beyond the division between medical and social solutions and see the providers of health care, particularly in the private sector, as an important and needed link to any needed social services.

It is only appropriate to conclude with a brief quote from the 1992 Robert Wood Johnson Foundation Report on Medical
Education: "Medical education must therefore include behavioral, social, probabilistic and informational sciences as well as ethics. The aging of the American population and altered patterns of illness and disability suggest that the challenge future physicians will face is less that of curing patients than of helping them maintain their functionality" (Marston, 1992).

\section{ACKNOWLEDGEMENTS}

I also wish to thank Barbara Barer and the staff of Ther $85+$ Study for all of their assistance.

\section{RESUMO}

\section{JOHNSON, C. L. A Manutenção da Vida}

Comunitária dos Idosos: Aspectos Médicos e Assistenciais. Cad. Saúde Públ., Rio de Janeiro, 10 (2): 149-163, abr/jun, 1994. O crescimento nos níveis de esperança de vida nos Estados Unidos da América tem sido acompanhado por um número crescente de pessoas inválidas nos seus 80-90 anos de idade, aumentando as demandas sobre os serviços de saúde e de assistência social. Este trabalho apresenta os resultados de investigação longitudinal, realizada com 150 indivíduos deidade superior a 85 anos. Ao longo de três anos, a capacidade funcional dos integrantes da amostra no desempenho de atividades rotineiras diárias declinou significativamente, ao mesmo tempo que os mesmos continuavam a referir sua saúde como sendo boa e a expressar contentamento sobre suas vidas. As famílias foram ativas no suporte à vida comunitária dos idosos mais velhos. Os de maior risco de institucionalização foram aqueles sem filhos. Ao longo do tempo, $48 \%$ dos sobreviventes permaneceram funcionais, enquanto $28 \%$ tornaram-se cada vez mais inválidos e dependentes, enquanto $24 \%$ permaneceram estáveis, apresentando alto grau de invalidez. As formas através das quais os idosos mais velhos lidavam com sua invalidez incluíram medidas no sentido de simplificar seu ambiente e reduzir seu mundo social. Eles 
também lançaram mão de regulação cognitiva através da modificação de suas crenças sobre saúde, delimitando aquelas áreas sobre as quais eles podiam exercer algum controle.

Palavras-Chave: Velhice, Longevidade; Assistência Médica; Assistência a Idosos

\section{REFERENCES}

BOWLING, A. \& BROWNE, R., 1991. Social networks, health and emotional well-being among the oldest old in London. Fournal of Gerontology, 46: 320-332.

CORNONI-HUNTLEY,J;BOCK,B; OSTFELD, A; TAYLOR, J. \& WALLACE, R., 1986. Established Populations for Epidemiological Studies of the Elderly. Washington, DC: National Institute on Aging. (NIH Publication No. 86-243)

DEAN, K., 1992. Health-related behavior: concepts and methods. In: Aging, Health and Behavior (M. Ory, R. Abeles \& P. Lipman, eds.), pp. 27-56, Newbury Parka: Sage.

DUKE UNIVERSITY, 1976, OARS: Older American Research Services Center Instrument. Durham: Duke University.

FRIES, J., 1980. Aging, natural death and the compression of morbidity. New England Fournal of Medicine, 303: 130-135.

GURALNIK, J., 1991. Prospects for the compression of morbidity: the challenge posed by the increasing disability in the years prior to death. Fournal of Aging and health, 3: 138-154.

JOHNSON, C. \& TROLL, L., 1992. Family functioning in late late life. Fournal of Gerontology (Social Sciences), 47: 566-72.

KATZ, S.; FORD, A.; MOSKOWITZ, R.; JACKSON, B. \& JAFFEE, M., 1963. Studies of illness in the aged: the index of ADL. Fournal of the American Medical Association, 185: 94ff.

KOVAR, M., 1986. Aging in the eighties. Advanced Data (U.S. Department of Health and Human Services), No. 115, May 1.

LEVENTHAL, J.; LEVENTHAL, E. \& SCHAEFER, P., 1992. Vigilant Coping and health behavior. In: Aging, Health and Behavior (M. Ory, R. Abeles \& P. Lipman, eds.), pp. 174-206, Newbury Parka: Sage.
LONGINO, C., 1988. Who are the oldest Americans? The Gerontologist, 28: 515-523.

LONGINO, C. \& SOLDO, B., 1987. The graving of America: implications of life extension for the quality of life. In: Health in Aging: Sociological Issues and policy Directions (R. Ward \& S. Tobin, eds.),pp. 58-85, New York: Springer.

MANTON, K. \& SUZMAN, R., 1993. Forecasting health and functioning in aging societies: implications for health care and staffing needs. In: Aging, Health and Behavior (M. Ory, R. Abeles \& P. Lipman, eds.), pp. 327-357, Newbury Park: Sage.

MARSTON, R., 1992. The Robert Wood Johnson Foundation Commission on Medical Education: The sciences of medical practice, Summary Report. Fournal of The American Medical Association, 268: 1144-1145.

RILEY, M. \& BOND., K., 1983. Beyond ageism: postponing the onset of disability. In: Aging in Society: Selected Review of Recent research, (M. Riley, B. Hess \& K. Bond, eds.), pp. 243252, Hillsdale: Lawrence Erlbaum.

RODIN, J. \& TEMKO, C., 1992. Sense of control, aging and health. In: Aging, Health and behavior (M. Ory, R. Abeles \& P. Lipman, eds.), pp. 174-206, Newbury Park: Sage.

ROSENWAIKE, I., 1985. A demographic portrait of the oldest old. Milbank Memorial Fund Quarterly, 63: 187-205.

SHANAS, E., 1979a. Social myth as hypothesis: the case of family relations of old people. The Gerontologist, 19: 3-9.

, 1979b. The family as a social support system in old age. The Gerontologist, 19: 169174.

SOLDO, B. \& MANTON, K., 1985. Changes in health status and service needs of the oldest: current patterns and future trends. Milbank Memorial Fund Quarterly, 63: 286-323.

TAEUBER, C. \& ROSENWAIKE, I., 1992. A demographic portrait of the oldest old. In: The Oldest Old (R. Suzman, D. Willis \& K. Manton, eds.), pp. 17-49, New York: Oxford.

TURNER, V., 1969. The Ritual Process. Ithaca Cornell.

VERBRUGGE,L., 1984. Longer life but worsening health: trends in health and mortality of middleaged and older people. Milbank Memorial Fund Quarterly, 62:475-519. 